JPPUMA: Jurnal Ilmu Pemerintahan dan Sosial Politik UMA Uournal of Governance and Political Social UMA), 8 (2) (2020): 142-153, DOI: https://doi.org/10.31289/ippuma.v8i2.3614

JPPUMA: Jurnal Ilmu Pemerintahan dan Sosial Politik UMA (Journal of Governance and Political Social UMA)

\title{
The Prosperous Justice Party of Bandung City and its Mix Strategy Marketing in the 2019 Election
}

\author{
Muhammad Taufiq*, Mudiyati Rahmatunnisa \& Ferry Kurnia Rizkiyansyah \\ Department of Political Science, Faculty of Social and Political Sciences \\ Universitas Padjajaran , Indonesia
}

Received: April 22, 2020; Reviewed: May 31, 2020; Accepted: June 16, 2020

\begin{abstract}
Abstrak
General Election (Pemilihan Umum/Umum) is an arena for political parties to fight for seats in parliament through various political campaign strategies they carry out. The success of the Prosperous Justice Party (PKS) Bandung City in obtaining the majority of 13 seats in the 2019 Election is an interesting political case to study. This study aims to describe and analyze the political marketing strategies that the legislative candidates from the Prosperous Justice Party (PKS) of Bandung City carry out. Using the marketing mix theory, this study looks at 4 dimensions, namely Product, Place, Price, and Promotion. A descriptive-qualitative approach is applied. This study conducts interviews with representatives of the former PKS candidates who were the members of the parliament of Bandung City in the period of 2019-2024. This study indicates that PKS candidates for the City of Bandung Parliament have succeeded in implementing a marketing mix strategy. They employ it effectively and efficiently and reach a wider and more inclusive segment. They also apply campaign narratives that are close to voter's needs through direct marketing strategies.
\end{abstract}

Keywords: Marketing; Mix strategy; Prosperous Justice Party; Parliament Candidate.

How to Cite: Taufiq, M., Rahmatunnisa, M., \& Rizkiyansyah, F.K., (2020). The Prosperous Justice Party of Bandung City and its Mix Strategy Marketing in the 2019 Election. JPPUMA: Journal of Governance and Social Politics UMA (Journal of Social and Political Governance UMA), 8 ( 2 ): 142-153

*Corresponding author:

ISSN 2549-1660 (Print)

E-mail: isvahan@aneukaceh.com ISSN 2550-1305 (Online) 


\section{INTRODUCTION}

Every political party targets to win General Elections (Pemilu). Every party makes a periodic agenda to achieve it. In the context of Legislative Election (Pileg), political parties struggle to gain as much as seats in parliament through their candidates. These candidates usually work collaboratively with political parties to formulate campaign strategies to get elected.

Several factors influence the electability of a candidate. Prothro et al. (1988, in Alsamydai and Al Khasawneh, 2013) argue that the voter's decisionmaking factor greatly determines the electability. Further, he states that the environment in which the voters make the decision is also necessary to consider since it influences the individual voters' judgment. Meanwhile, according to Michael S. Lewis-Beck and Tom W. Rice (1992), three factors make voters decide to vote for a political candidate, namely: issue, party identification, and candidate attributes.

The above factors have been included in the political marketing strategy that every candidate takes into account. In the studies on electoral systems, political marketing is one of the fields of inquiry applying theories of voting behavior and economic marketing. It deals with political parties' marketing strategies, candidates, and ideas to campaign to the public (Surbakti, 2016).

This study aims to describe and analyze the political marketing strategies that legislative candidates of the Prosperous Justice Party in Bandung undertake in the 2019 General Election. This study uses the theory of the marketing mix strategy formulated by Niffenegger (1988, in Cwalina, et al., 2015), which consists of four dimensions, namely product, place, price, and promotion. Niffenegger (1988, in Cwalina, et al., 2015), illustrates the process of political marketing as drawn in the following chart.

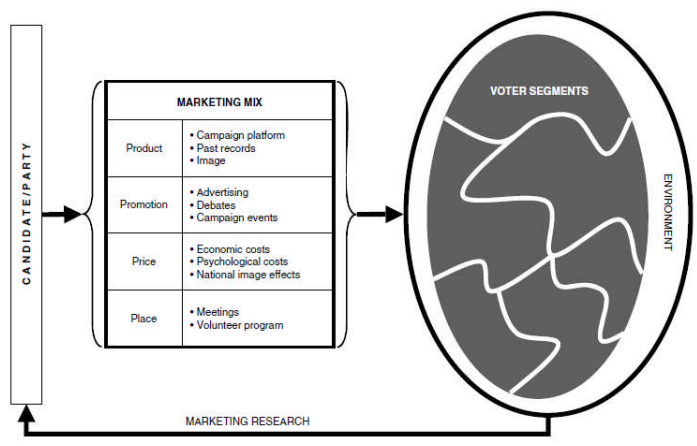

Figure 1. The Political Marketing Process, according to Niffenegger Source: Cwalina, et al. (2015)

According to Niffenegger (1988, in Cwalina, et al., 2015), a 'product' is a variety of 'benefits' that are believed to be obtained by voters if the candidate they choose gets elected. As for the promotion is socializing activities. It offers and persuades the public to choose a certain candidate or party through a series of publications and advertising activities. Furthermore, place in the context of political marketing is the ability of a candidate to be able to convey campaign messages in person. Finally, the price is the total cost borne by voters if the candidate they choose is elected.

\section{RESEARCH METHODS}

This research applies descriptive mapping with qualitative methods. The aim is to reveal and understand something behind the phenomenon hidden from the public view (Strauss \& Corbin, 2003). The researchers use the theory of mixed marketing strategy as an analytical tool to dissect the practice of political marketing strategy that the candidate of legislative members of Bandung City undertakes in the 2019 Elections. From the marketing strategy, the theory derives variables into four dimensions, namely the product, promotion, place, and price.

This study uses relevant information as research materials. From the way to obtain the materials, there are two kinds of sources used in this study, namely primary data sources through interviews and secondary data sources through literature and documentary methods. The informants 
in this study are those who are related to the topic and can support the explanation of the research question. Therefore, the informants are selected based on the consideration purpose of the efforts to answer the question or purposiveness. In this case, the informants who have been interviewed are the representatives of the elected candidates, the chairman of the regional branch of PKS of Bandung City, the chief of the PKS of Bandung City's Committee for General Election Strategy (BAPILU), political observers and representatives of the mass media. Meanwhile, to test the validity of the data, researchers used the source triangulation technique by comparing and checking the degree of confidence of information obtained through different time and tools in qualitative research (Patton in Moleong, 2005).

\section{RESULTS AND DISCUSSION}

The regional branch of PKS of Bandung City and its legislative candidates managed to take advantage of the marketing mix strategy, which consists of four dimensions, namely the product, promotion, place, and price. In practice, They carried out these four dimensions effectively and efficiently during the campaign process in the 2019 General Election. As the result, they succeeded in improving their achievement compared to the previous election, in which they increase the number of seats in the local parliament from 6 seats in 2014 to 13 seats in 2019.

The 2019 General Election for legislative members of Bandung City involved 719 candidates from 15 political parties. These candidates competed for 50 seats representing six electoral districts (Daerah Pemilihah/Dapil). The political parties participating in this election were the participants of the 2014 Election, except for the Indonesian Justice and Unity Party (Partai Keadilan dan Persatuan Indonesia/PKPI). The result places PKS as the top ranking. PKS won the election by obtaining 295,615 votes (19.5\%) and two candidates have been elected mostly in every electoral district. While four PKS' candidates have been elected in one of the districts called Dapil 4.

Although this marketing mix strategy is interpreted differently by each legislative candidate, in practice, its implementation tends to be typical. Every PKS candidate has similarities in the marketing strategy themselves. A simple indication is the similarity of the vision, mission, and programs of the candidates, which are following the party's platform and strategy. They are relatively consistent in following the campaign strategy that the party outlined.

\section{Product}

According to Niffenegger (1988, in Cwalina, et al., 2015), political products are a variety of benefits that the voters believe to obtain if the candidate whom they give their votes will be elected.

The Chairman of the regional branch (DPD) PKS Bandung City, Tedy Rusmawan, ST. MM., reveals that PKS Bandung City in the 2019 Election offered 27 old candidates and 23 new candidates. Of the 27 candidates, three of them have been reelected as the members of the Bandung City Parliament for the succession period of 2019-2024. The candidates are namely: 1 ) Hj.Salmiah Rambe, S.Pd.I; 2) Tedy Rusmawan, ST., MM.; 3) Yudi Cahyadi

The above 50 candidates in total are PKS' cadres who have been trained in the party's regeneration system thoroughly (Interview with Tedy Rusmawan, ST., MM). This phenomenon is in line with research by Djuyandi \& Sodikin (2019) which reveals that a PKS cadre must have been trained in a rigorous regeneration process before being allowed to occupy strategic positions in government institutions. For this reason, in the context of General Election, PKS rarely takes candidates from the outside of the party, 
except those who submit as the member of the party and meet the procedures applied in the internal training system.

According to Yudi Cahyadi who is one of the incumbent candidates for the Parliament of Bandung City, the process of selection of legislative candidates in the internal of PKS consists of several stages. It starts from the internal screening stage involving input from administrators at each level to the decision-making stage carried out authoritatively by the Regional Executive Council (DPD) PKS. Yudi further explained that PKS has an internal selection mechanism that involves the participation of cadres, input from the sub-district to the district level, which is then decided by the DPD management. This confirms that the selection of the candidates is considered as the assignment from the party, not based on one's initiative (Interview with Yudi Cahyadi).

What the PKS is doing in selecting candidates seems to take into account the alignment of the profiles of candidates with the party platform. Aminuddin \& Ramadlan (2012) explain that, in the mechanism of selecting candidates, political parties should select candidates for two reasons. First, because of the consideration of mass supporters, do the candidates have a good connection and have strong support from the grassroots? Second, because of the similarity of political parties' platform with the framework of the candidates. In this case, the personal platform of the candidate should be following the party's ideology or platform.

Since all PKS' candidates come from the internal party members or cadre, it has consequences directly or indirectly to the products offered by the candidates, which are their profiles, their campaign platform, track record, and their image in public.

\section{Campaign Platform}

According to Niffenegger (1988, in Cwalina, et al., 2015), the campaign platform is the dimension of the first product. In this case, Cwalina, et al. ( 2015 ) connect it to the leadership of candidates, their image, issues, and policies that they support. The platform contains a series of visions, programs, missions, and commitments (promises) designed and marketed by legislative candidates in their campaign. In this case, all candidates who come from the internal party tend to be more easily managed from top-down direction by the party to market a synchronized campaign platform with the party's vision, mission, and program.

This research shows that all PKS candidates for Bandung City are campaigning on a symmetric platform with the national PKS program, which is determined by the PKS national council. Some examples of issues in the campaign are the lifetime driving license (SIM) and the elimination of motorbike tax. This program turned out to become very effective in gaining votes because it was considered real and close to the needs and expectations of the general public.

As a political party with Islamic ideology as its platform declaring itself as a da'wah party, PKS of Bandung City uses campaign narratives that are common and inclusive. It is obvious from the programs and mission that the PKS candidate offered to voters. An example is what Sandi Muharam, SE did in his campaign, in which he brought forward the mission of "Realizing Community Aspirations". Sandi chose narratives that did not emphasize religious symbols too much (Interview with Sandi Muharam, SE).

Pragmatically, PKS's choice to become an open party has started since 2008. Nurussa'adah and Sumartias (2017) explain that PKS has emphasized its existence to be more open in communicating and collaborating with other stakeholders of national politics as its decision at the Conference for National Program (Musyawarah Kerja Nasional/Mukernas) in Bali, February 1-3 2008. This was reaffirmed in the Second 
National Conference (Musyawarah Nasional/Munas) on June 16-20, 2010, in Jakarta, which made PKS an inclusive party.

Since then, this transformation seems to have made PKS and its candidates in every election market more general and inclusive programs. An example is by raising issues of economy, legal justice, education, and the like. A member of the Editorial Board of a local press Radar Bandung Azam confirmed that PKS in the 2019 Election was an inclusive and populist party (Interview with Azam). In their study, Muchtar and Aliyudin (2019) argue that PKS has been trying to make changes to a more open and popular orientation, so that it is no longer an exclusive party.

However, it does not mean that PKS's exclusive character just disappears. It is evident that they only recruit candidates for a legislative member from their cadres. Apart from that, Firman Manan reveals that they also still maintain their loyal ideological supporters at the grassroots level (Interview with Firman Manan, Political Observer of UNPAD).

We would conclude that PKS Bandung legislative candidates use a campaign platform to attract sympathy and support from voters in their electoral districts. The campaign platforms are mostly general and inclusive, especially by bringing up economic issues. However, there are still a small number of candidates who campaigned their religious programs to attract ideological Muslim voters.

\section{Past Record}

According to Niffenegger (1988, in Cwalina, et al., 2015), the record is the second dimension of the product. Track records are historical profiles of legislative candidates in the voters' view, both personal, professional, and political. In this sense, both new and incumbent candidates have their track records. This track record is very important in a political marketing strategy since a well-known product will be much easier to sell than a new product. This makes incumbent candidates more confident in campaigning their programs. In contrast to incumbent candidates highlighting their track record, the new candidates create an image of strong personal and professional track records (Interview with $\mathrm{Hj}$. Salmiah Rambe, S.Pd.I).

In this case, we would conclude that incumbent candidates tend to promote their track records of performance as legislative members in the previous period and campaign for their contribution to the progress of Bandung City. To explain this, we refer to the job advantage theory by Nikmah (2015), which explains that the incumbent candidates are more profitable in serving constituents as they have access to resources that can bring benefits to their campaigns. Meanwhile, the new legislative candidates put more emphasis on their personal and professional track records, which are amplified and capitalized in their campaign.

\section{Image}

According to Niffenegger (1988, in Cwalina, et al., 2015), the image is the third dimension of the product. The image in this context is a reputation presented by a legislative candidate to the public. In this case, the most PKS candidate has a good image. They have been selected by the party leadership to become a legislative candidate. Meanwhile, PKS's image itself as a party is also getting better in the city of Bandung. The increase of votes and the seats in parliament acquisition indicates compared to the previous election indicates improvement. The effect of the good image is that the public trust in PKS is also getting stronger. In this case, the party appears to have re-established its brand as a party close to the urban middle-class young voters group. One of them is by promoting younger generations of politicians as legislative candidates (Interview with 
Firman Manan, Political Observer of UNPAD).

Jefkins (in Jefkins \& Yadin, 2004) describes that the image has five types. First, the mirror image or shadow image, which is the image inherent in a person or members of the organization with the perception of outsiders about the organization. Second, the current image or the prevailing image, which is the image adopted by outsiders about an organization and an individual determined by the amount of information they receive and trust. Third, multiple images, which are different images from the public perspective of an organization caused by the behavior of different people representing the organization. Fourth, corporate image or organizational image, which is the image of an organization as a whole and not just an image of its products. Fifth, wish image, or expected image, which is the image desired by the organization.

In this case, each PKS individual seems to create various images of self and the organization at the same time, where each candidate constructs a different image but not counterproductive to the party's image. At the same time, they are also trying to build the image of the organization as a party that takes the side of people and cares about the prosperity of the community through several issues promoted in a political campaign, such as the motorbike

tax elimination program and life-long driver's license, which are the main programs of PKS. (Interview with Tedy Rusmawan, ST., MM).

\section{Promotion}

According to Niffenegger (1988, in Cwalina, et al., 2015), promotion is an activity to socialize, offer, and persuade people to elect a particular candidate or party through a series of advertising and publication activities. This study indicates that the PKS candidates for Bandung City have a promotion strategy with two channels. First, the personal line, which is a promotional program carried out independently by the conditions and circumstances of the candidate's resources. Second, the party line, which is a general promotion program carried out collectively that aims to build awareness or public knowledge of the party, not of each candidate.

For this promotion strategy, PKS candidates rely more on direct promotion to the public and are carried out offline or what they call 'direct selling'. In this case, Iwan Hermawan as the head of the Bandung City PKS BAPILU explained that PKS in the 2019 Election implemented a more expansive strategy through direct selling from house to house. Furthermore, he describes that what DPD PKS has done is to show a coordinator for each electoral district (dapil) to the public, whose tasks are to do directly in each electoral district (Interview with Iwan Hermawan).

Although they use mainstream media and social media, the percentage is relatively small. In their view, the promotion with media is more suitable for central or provincial legislative candidates who have wide coverage of electoral districts. whereas, for candidates at the city level, they believe that direct promotion to constituents is more effective. They rely more on their closeness and network with communities (Interview with $\mathrm{Hj}$. Siti Nurjanah, SS).

\section{Advertising}

Advertising is the first dimension of promotion in marketing mix theory (Niffeneger, 1998, in Cwalina, et al., 2015). Advertising is a communication strategy carried out by legislative candidates through the media to socialize themselves and persuade voters. In this case, the candidate's advertising strategy is made online and offline.

Although the promotion through online media is considered effective in the 
context of young voters in Bandung City, PKS candidates at the city level are generally more focused on doing offline advertising than online. Most candidates chose to install more Campaign Props (APK), share calendars, and communicate directly with constituents. We would argue that the candidates optimize advertisements through campaign props (APK) as 'direct selling strategies (Interview with Khairullah, S.Pd.I).

In terms of content, PKS candidates mostly use 'issue ads'. According to Danial (2009, in Retnowati, 2013), issue ads are candidate advertisements focusing on issues related to the general public or public policy. In this case, the candidates mostly concentrate their campaigns on economic issues (Interview with Tedy Rusmawan, ST., MM).

\section{Debates}

The debate is the second dimension of promotion (Niffenegger, 1988, in Cwalina, et al., 2015). It is an activity to contest ideas, vision, mission, a program from each legislative candidate. In this case, the debate is one of the important programs in every democratic election so that voters can make rational choices. However, the General Election Committee (KPUD) of Bandung City did not hold a debate program between legislative candidates in the 2019 Election, as in general debates in the Presidential Election or Gubernatorial Election. The candidates rather deliver their vision and mission in the campaign event such as in a public rally.

According to Myles Martel (in Damayanti \& Hamzah, 2017), a political campaign debate is a joint appearance of two or more opposing candidates, who occupy their respective positions, with direct statements to gain support. Meanwhile, according to JJ Auer (in Damayanti \& Hamzah, 2017 ), a debate program must have several conditions, including confrontation, balance and sufficient time, equal candidates, statement propositions to the public.

KPUD of Bandung City does not have a debate program for legislative candidates (Interview with the KPUD of Bandung City). It seems that in Indonesia the debate program between candidates is not yet popular and is only limited for debates between candidates for the head of the executive (Presidential or Gubernatorial Election. Therefore PKS does not make use of the debate program as a tool for a campaign (Interview with Sandi Muharam $\mathrm{SE}$ ).

\section{Campaign Events}

Campaign events are the third dimension of promotion in marketing mix theory (Niffenegger, 1988, in Cwalina, et al., 2015). This is a series of direct promotional activities carried out by legislative candidates for supports from constituents. In this case, campaign events that are usually carried out in elections include public rally, 'door to door" promotions, and exhibitions.

The results show that PKS candidates did not expect too much to get electoral incentives from activities such as a public rally. Instead, they put more emphasis on door-to-door promotions and/or community events. This is because the citylevel candidates must be closer to their constituents than the central and provincial candidates (Interview with Tedy Rusmawan, ST., MM). Such a door to door campaign strategy has done by the PKS candidate since 2009. Aminull (2010) describes that one of the more effective campaign strategies is direct interpersonal communication with 'going down to the grassroots' (turun ke bawah).

The event such as the exhibition is minimum. They held photo exhibitions, but only occasionally. So it can be concluded that PKS candidates use campaign events to get votes, but emphasize and more focus on door-to-door strategy rather than mass 
gathering activities (Interview Salmiah Rambe, S.Pd.I).

\section{Place}

According to Niffenegger (1988, in Cwalina, et al., 2015), Place in the context of political marketing is the ability of PKS candidates to convey personally their campaign messages to the public. It deals with the presence of candidates among voters in their electoral districts (Dapil). In this case, the PKS candidates seem to maximize the support of their voters effectively in their respective electoral districts. The campaign was conducted in their respective electoral district without overlapping the other candidates in the same electoral district (Interview with Tedy Rusmawan, ST., MM).

The campaign pattern of PKS candidates in their respective electoral districts shows regularity and well managed. There is no friction between candidates within the party, although friction occurs occasionally with other party candidates. In terms of place related to the area of the basis of political ideology supporters, PKS candidates can also mingle with the base of cross-organizational communities, such as members of NU, Muhammadiyah, Persis, and others (Interview with Khairullah, S.Pd . I). The PKS mass base is mostly among young people, especially in school Islamic activists (Rohaniawan Islam/Rohis) and the Islamic Activists at University (Lembaga Dakwah Kampus/LDK). PKS in Bandung can also communicate with various ideological platforms and varied ideological communities, not only on campus. This is what makes PKS Bandung have large and wide market potential.

\section{Meetings}

According to Niffenegger (1988, in Cwalina, et al., 2015), the meeting is the first dimension of the place in the theory of the mixed marketing strategy. This is an activity that presents or brings together legislative candidates with constituents in their electoral area. In this case, PKS candidates hold various meetings while campaigning. The meetings were divided into 3 categories, namely meetings with core cadres and PKS members, meetings with PKS sympathizers, and meetings with relatively fluid voters.

Meetings with core cadres are to strengthen internal consolidation in campaign activities. Meanwhile, meetings with sympathizers are more to defend the previous voters (wherein the previous period PKS won 6 seats in the parliament of Bandung City). In the 2019 Election, PKS was more proactive in targeting more fluid communities who did not always have ideological preferences.

The forms of meetings they hold with potential voters are not only door to door and the like. They did quite a lot of creative and millennial campaign actions, one of which was by holding a flashmob. Andani, Taqwa \& Suleman (2019) explain that flashmob is a longmarch activity using PKS attributes and distributing campaign props such as stickers to the public.

For PKS, the flashmob is an effective method to create more collective awareness of the people of Bandung because it takes place on the side of the road in which many people can see it. The method used is also quite creative and well prepared. They made flashmob from Pasteur to Sukamiskin. In the flashmob, they greet and tell the public about PKS political promises, including the elimination of motorbike tax and life-long driving licenses (Interview with Tedy Rusmawan, ST., MM).

In this respect, we would conclude that the meetings that PKS candidates held were using various methods to reach various segments of voters. Pragmatically, this strategy seems necessary to get a big vote.

\section{Volunteer Program}


According to Niffenegger (1988, in Cwalina, et al., 2015), volunteer programs are the second dimension of place in the marketing mix theory. Voluntary programs are organized free of charge and are oriented towards providing free benefits to constituents to attract sympathy. In this case, programs such as social services, health services, and educational assistance are not a priority for the majority of PKS candidates in Bandung. Most of them view that such activities require substantial funding so that they are not popular with them (Interview with Khairullah, S.Pd. I).

There are only a few candidates who carry out a campaign strategy in the form of providing social assistance. However, they tend to be careful not to get accused of violating campaign rules (Interview with $\mathrm{Hj}$. Siti Nurjanah, SS). So, the campaign through volunteer programs is still attractive to candidates because it touches directly with the needs and expectations of voters. However, it appears that this type of campaign is a booster to build publicity.

\section{Price}

According to Niffenegger (1988, in Cwalina, et al., 2015), price is the total cost borne by candidates and voters if the candidate they choose gets elected. These costs can be kinds of economic costs, psychological costs, and national image effects.

In general, the economic costs borne by each PKS candidate are fairly lower compared to that borne by candidates from major parties and the ruling party. On average, PKS candidates for the city of Bandung spend their funds in the range of tens, not even hundreds of millions. Although there are candidates who spend up to hundreds of millions of rupiahs, they are not many (Interview with Yudi Cahyadi).

Almost all PKS candidates are also financially supported by the party. The funds are raised from the contribution of the party's members and sympathizers. However, the party's financial support is only a stimulus. Candidates must still pay their expenses (Interview with Tedy Rusmawan, ST., MM).

So it can be viewed that the costs in political marketing activities are borne by both the candidates, the party cadres, and sympathizers. In this case, the candidates personally spend their campaign funds, but it is also stimulated by the party.

\section{Economic Cost}

Economic costs are the first dimension of price in the marketing mix theory (Niffenegger, 1988, in Cwalina, et al., 2015). This is the cost spent by the candidate in the forms of financial or other materials to support the campaign program.

According to Surbakti \& Supriyanto (2011), political party revenue comes from three sources. First, internal party sources, such as membership fees and cadre contributions, from the State Revenue and Expenditure Budget (APBN), as well as from the community, both individuals and/or organizations. In this case, PKS candidates in Bandung rely more on the internal and external party sources.

Apart from the costs borne by the individual candidates and that of borne by the party, PKS candidates also get financial support from their sympathizers. So far, PKS is still viewed as an ideological party that fights for the interests of Muslims. This makes the ideological Muslim community sympathize with PKS and support its struggle in parliament. This encourages some of the volunteers and their sympathizers to provide support, including material support (Interview with $\mathrm{Hj}$. Salmiah Rambe S.Pd.I)

The contribution given by PKS supporters were quite large, almost equivalent to the costs incurred by the candidates. Such mutual financial cooperation has become a tradition among PKS cadres. PKS cadres and sympathizers 
gave this assistance sincerely and voluntarily (Interview with Khairullah, S.Pd. I).

So it can be concluded that the economic contribution given by the voters is quite significant in supporting the political marketing program of the PKS legislative candidates in Bandung City. The militancy of PKS cadres and supporters is a separate force that contributes significantly. According to Damanik (2002, in Triono, Kartini \& Sulaeman, 2018), the militancy of PKS cadres is a reflection of the patriotic character which is one of the seven characters of PKS cadres. These characters are moralist, professional, patriotic, moderate, democrat, reformist, and independent.

\section{Psychological Cost}

Psychological cost is the second dimension of price in the marketing mix theory (Niffenegger, 1988, in Cwalina, et al., 2015). This is a mental burden borne by candidates and voters during the campaign period. The psychological burden is felt by both PKS candidates and volunteers. One of the main factors that create the burden is the long campaign period (around 7 months). This made them feel exhausted in conducting campaigns (Interview with Yudi Cahyadi).

Some candidates also feel burdened because they feel they have limited resources. Sometimes they only get assistance from their sympathizers. However, in terms of electability, most candidates admit that the psychological burden they bear is not that great, because for them politics is part of the dedication and the struggle for da'wah, as well as a mandate from the party (Interview with Sandi Muharam, SE).

To overcome the psychological burden the DPD PKS Bandung City makes clear rules and division of work areas so that there is no overlapping between candidates. This method aims to avoid conflict between the candidates and at the same time avoid potential conflicts with other parties' candidates. The candidates are divided into different electoral districts so that they do not target the same area and voters (Interview with Tedy Rusmawan, ST., MM).

\section{National Image Effect.}

The effect of the national image is the third dimension of the price (Niffenegger, 1988, in Cwalina, et al., 2015). This is the multiplier side effect that the image of the party at the central level brings to the image of the legislative candidates in their constituents. The effect of this national image has more or less affected the image of parties and legislative candidates at the local level.

At the national level, PKS is often attacked with black campaigns by labeling it as an Islamic party that tends to be radical, one of which is the label "Wahabi". In the 2019 Election, PKS was also labeled as a party that plays identity politics narratives by bringing up religious issues. However, the labeling does not target personal candidates, but rather PKS as a party (Interview with Yudi Cahyadi).

According to Juditha (2014), a black campaign is the delivery of information that is attacking, blaming, throwing accusations, spreading incorrect information about the political opponents, which is not necessarily confirmed with facts. According to the head of the Bandung City PKS DPD Tedy Rusmawan, ST., MM, the black campaign in Bandung is not affecting too much. Even though there are a few and only limited on social media and less than the 2018 Pilkada where PKS cadres Oded M. Danial became one of the candidates in the Bandung Mayor Election.

It seems that the black campaign against PKS candidates in Bandung City can be managed effectively by the candidates in the field while conducting the campaign. Although some candidates 
develop a religious image and play religious issues in their campaigns, this tends to be less dominant. What they emphasize more is the common issues, in which they offer solutions according to community needs (Interview with Tedy Rusmawan, ST., MM). It can be concluded that the effect of PKS national image does not have a significant impact on the electability of candidates in Bandung City. This is because each region has its issues and challenges that are not necessarily duplicated from the national issue.

\section{CONCLUSION}

PKS of Bandung City succeeded in increasing their achievement of seat acquisition from 6 seats in 2014 to 13 seats in the 2019 Election, in which the legislative candidates used an effective and efficient marketing mix strategy. This strategy is formulated in a clear and structured manner by the party, then implemented in the field with the solidity and militancy by the legislative candidates.

Of the product that is offered, the candidates successfully market their programs off the lifetime driver's license and the elimination of motor tax in the campaign. The program is effective in gaining votes because it is real and close to the needs of the general public. Besides, they use more inclusive campaign narratives to target a wider segment, even though they identify themselves as a youth party. While in promotion, the candidates mostly carry out direct promotions to the public or 'direct selling'. Most candidates prefer to go directly to their constituents by the door to door promotions and/or through community events.

From the aspect of the campaign place, the candidates campaigned following their respective area of constituents without overlapping with other fellow PKS candidates in the same electoral district. Meanwhile, in the context of the basis of political ideology, they are also able to compete with the basis of multi- organizational communities. In terms of price, the economic costs borne by each candidate come from the personal budget and also from the party as a stimulus. They also receive voluntary financial assistance from some sympathizers. Apart from economic costs, they also have to pay psychological costs in bearing accusations through labeling and black

campaigns. Yet, the existing labeling tended to be only to parties, not to personal legislative candidates.

\section{REFERENCES}

Alsamydai, M. J. \& Al Khasawneh, M. H. (2013). Basic Criteria for the Success of the Electoral Candidates and their Influence on Voters' Selection Decision. Advances in Management \& Applied Economics, 3 (3):105-127

Aminuddin, M. F \& Ramadlan, F. (2012). Efektivitas Keterwakilan Politik: Revitalisasi Fungsi Parpol dan Kompetisi Kandidat pada Sistem Daftar Terbuka. Jurnal Ilmu Politik AIPI, (22)

Aminulloh, A. (2010). Komunikasi Politik Dakwah Partai Keadilan Sejahtera pada Pemilu legislatif 2009. Jurnal Ilmu Komunikasi, 8(1): 26-35

Andani, M., Taqwa, R. \& Suleman, Z. (2019). Rekrutmen dan Kaderisasi Calon Legislatif Perempuan Pada Pemilihan Umum 2019 Oleh Partai Keadilan Sejahtera. Nusantara: Jurnal Ilmu Pengetahuan Sosial, 6(3): 427-444

Cwalina, W., Falkowski, A. \& Newman, B. I. (2015). Political Marketing; Theoritical and Strategic Foundantions. New York: Routledge.

Damayanti, N. \& Hamzah, R.E (2017). Strategi Kampanye Politik Pasangan Jokowi-Jk Pada Politik Pemilihan Presiden 2014. Wacana, Jurnal Ilmiah Ilmu Komunikasi, 16(2): 279 290

Djuyandi, Y. \& Sodikin, F. L. (2019). Proses kaderisasi Partai Keadilan Sejahtera dalam mempertahankan eksistensi partai politik menjelang Pemilu tahun 2014. Jurnal Society, 7 (1):12-22

Jefkins, F \& Yadin, D (2004). Public Relations terjemahan Haris Munandar. Jakarta: Erlangga

Juditha, C. (2014). Interpretasi Black Campaign Dalam Pesan Singkat Pada Pilkada Walikota Makassar 2013. Jurnal Penelitian dan Pengembangan Komunikasi dan Informatika, 5 (1): $53-60$

Lewis-Beck, M. S. \& Rice, T. W. (1992). Forecasting Elections. Washington: CQ Press. 
JPPUMA: Jurnal Ilmu Pemerintahan dan Sosial Politik UMA (Journal of Governance and Political Social UMA), 8 (2) (2020): 142-153

Moleong, L. J. (1999). Metodologi Penelitian Kualitatif. Bandung: Remaja Rosdakarya.

Muchtar, K \& Aliyudin. (2019). Public Relations Politik Partai Keadilan Sejahtera dalam Pemilukada Jawa Barat. Communicatus: Jurnal Ilmu Komunikasi, 3(1): 69-90

Nikmah, N. (2015). Kandidat Petahana DPRD Kota Surabaya Pada Pemilu Legislatif 2014 (Studi Deskriptif Caleg Terpilih Melalui Partai Kebangkitan Bangsa). Jurnal Politik Muda, 4(1): 100-107

Nurussa'adah, E. \& Sumartias, S. (2017). Komunikasi Politik Partai Keadilan Sejahtera (Pks) Dalam Keterbukaan Ideologi. Jurnal Kajian Komunikasi, 5(1): 43-52

Retnowati, Y. (2013). Efektivitas Iklan Dalam Meraih Partisipasi Politik. Wacana: Jurnal Ilmiah Ilmu Komunikasi, 12(3): 201-211
Strauss, A. \& Corbin, J. (2003). Dasar-dasar Penelitian Kualitatif. Yogyakarta: Pustaka Pelajar.

Surbakti, R. (2016). Tata Kelola Pemilu Sebagai Subkajian Pemilu Terapan. Pidato Inagurasi Anggota Baru Akademi Ilmu Pengetahuan Indonesia (AIPI), Fisip Universitas Airlangga.

Surbakti, R. \& Supriyanto, D. (2011). Pengendalian Keuangan Partai Politik (seri demokrasi electoral 10). Jakarta: Kemitraan Bagi Pembaharuan Tata Pemerintahan.

Triono, Kartini, D. S. \& Sulaeman, A. (2018). Militansi Kader PKS Dalam Pemenangan Politik Pada Pemilu Legislatif 2009 dan 2014 di Lampung. Jurnal TAPIS 14(2): 140-164 